\title{
REGULATORY ISSUES AND CHALLENGES: GLOBAL NORMS AND RELIGIOUS CONSTRAINTS
}

\author{
Syahraini $^{1}$, Mai Simahatie ${ }^{2}$, Prof. Shabri Abdul Majid ${ }^{3}$, Dr. Rita Handayani ${ }^{4}$, Dr. Marliyah ${ }^{5}$ \\ North Sumatra State Islamic University, Medan \\ Correspondence: syharaini@gmail.com
}

\begin{abstract}
Regulation is a balancing act. Different, often contradictory, goals - flexibility and consistency, freedom and strict controls, innovation and crisis-avoidance, consolidation and conflicts of interest, efficiency and consumer protection, openness and protection of national firms - must be applied in proper dosages by people familiar with the political and cultural environment. The audit systems and incentive structures must be flexible yet strict enough to allow innovation but prevent rogue operations. Before the disruptions of the 1970s, regulators performed a mostly technical task outside of the political limelight. In recent years however, virtually every country - including those with well-established regulatory authorities and traditions - has been rocked by banking crises. By October 1998, regulators worldwide were committed to the implementation of the 'Core Principles for Effective Banking Supervision' issued in 1997 by the Basle Committee. Similarly, as of March 1999, the 102 signatories of the December 1997 Free Trade in Financial Services Agreement (under the aegis of the World Trade Organization) were expected to liberalize their markets which is directed at literature research. In this case, The author takes two problems based on the description on the background problem. The formulation of the problem is How the Value of Islam in Islam The Era of Globalization and How Globalization Affects Religious Values Islam. The research methods include: the type of research Library Research is research through literature review or literature. The data sources in this study are primary data, namely books that directly discuss on the Effect of Globalization on Islamic Religious Values. Data analysis techniques used to get the conclusion is descriptive qualitative by drawing conclusions deductively, namely how to draw conclusions from the general to the specific. The author draws conclusions and suggestions that: the influence of globalization covers many aspects of life. However, that doesn't $t$ mean we cannot provide an understanding of globalization that includes all symptoms the. Looking at the aspects of globalization above, we can conclude that globalization is nothing but the application of rational and scientific knowledge to all activities in all areas of life or to all aspects Public.
\end{abstract}

Keywords: Financial Regulation, Ideological Debates, Changing Paradigm, Global Supervision, Making and Enforcement, Recent Developments

\section{INTRODUCTION}

The regulation of financial institutions was characterized by strict controls, clearly defined boundaries, and limits on foreign participation in the national market. Cartel-like arrangements within sectors prevailed, as well as stable relationships between borrowers and lenders. Financial markets were divided into distinct and clearly defined segments: commercial banks, investment banks, securities firms, insurance companies, etc. Interest rates were 'administered' as opposed to being left to market forces, and most financial operations were tightly regulated. Except for the United States and the United Kingdom, public ownership of banks (by federal or local governments) was common, allowing governments to channel credit to favored sectors of the economy. Even when banks belonged to the private sector, the logic was not fundamentally different, since governmentbank relations were defined by a quid pro quo: managers gave away some autonomy in exchange for protection from outsiders. To be sure, a measure of openness was allowed in many countries, but this did not prevent national firms from remaining somewhat insulated from foreign competition since 


\section{REGULATORY ISSUES AND CHALLENGES: GLOBAL NORMS AND RELIGIOUS CONSTRAINTS}

DOI: $10.54443 /$ ijebas.v2i1.137

the occasional authorization given to a foreign firm to operate in the domestic market was designed not to upset existing cartels.

An additional problem of regulation is one of resources. The knowledge and skills necessary to be a competent regulator in today's complex, uncertain and constantly changing environment are such that governments can seldom afford the best possible regulators. The private sector in contrast can afford those lawyers, strategists and product innovators who are in a position to keep the industry one step ahead of the regulators. In Islamic countries, the complications arising from international pressure are compounded by the added - and often conflicting - demands of religion. Religion is a touchy subject and has on occasion been used as a cover for fraudulent activities. Independence and integrity are all the more important since regulatory issues are even more likely than in a conventional setting to degenerate into major political crises. Furthermore, despite similarities with conventional ones, Islamic products and practices do not fit neatly into existing legal, regulatory and accounting systems. In addition to establishing standard prudential rules (concerning capital and reserve requirements, capital/assets and other ratios), Islamic banking regulators have to devise rules to govern such issues as new finance methods, conditions of ownership of Islamic institutions (minimum capital, maximum individual ownership, etc.), fiscal status of income, and the like. In sum, they must operate under the watchful eyes of 'markets' and religious authorities, while complying with international practices and standards. In addition to establishing standard prudential rules (concerning capital and reserve requirements, capital/assets and other ratios), Islamic banking regulators have to devise rules to govern such issues as new finance methods, conditions of ownership of Islamic institutions (minimum capital, maximum individual ownership, etc.), fiscal status of income, and the like. In sum, they must operate under the watchful eyes of 'markets' and religious authorities, while complying with international practices and standards. In addition to establishing standard prudential rules (concerning capital and reserve requirements, capital/assets and other ratios), Islamic banking regulators have to devise rules to govern such issues as new finance methods, conditions of ownership of Islamic institutions (minimum capital, maximum individual ownership, etc.), fiscal status of income, and the like. In sum, they must operate under the watchful eyes of 'markets' and religious authorities, while complying with international practices and standards. and the like. In sum, they must operate under the watchful eyes of 'markets' and religious authorities, while complying with international practices and standards. and the like. In sum, they must operate under the watchful eyes of 'markets' and religious authorities, while complying with international practices and standards.

The real global worldwide or universal."' Brings the sense of the loss of geographical boundaries in the context of development of values and ideology. Therefore, in the era of human globalization, live in an open world. Openness that pervades all human life, both physically, psychologically, socially, religiously and educationally Today Isiam education is in an era of globalization which is marked by the strong economic pressures in life, the demands of society to obtain more fair and democratic treatment, use of technology sophisticated, interdependence, and strong hedonistic cultural values, pragmatic, materialistic, and secularistic. The emergence of various trends in the era of globalization are: is a challenge and at the same time an opportunity if it can be faced and solved wisely and wisely, namely by reformulating various components of education: vision, mission, goals, curriculum, learning process teaching, and so on.' Facing such a situation, the world of education in general, and Islamic education in particular is now at a crossroads, namely between ways to follow the external pull as the influence of the era of globalization, or internal attraction which is the main 
mission of education, namely a complete human being, that is, a human being who has fully developed his potential balanced. In the face of external and internal pulls, New dynamics emerge in Islamic education, namely the effort to review all its components in an innovative, creative, progressive, holistic, and adaptive manner with the demands of modernity. Efforts to modernize Islamic education are now on the national agenda as reflected in the spirit contained in law concerning the National Education System. In the law In this context, various strategies for improving the quality of education can be found in order to answer the modern challenges and the challenges of globalization. That is: "Law Number 14 of 2005 concerning teachers and lecturers; government regulation No. 27 of 2007, concerning Teacher and Lecturer certification. In line with that, there is also a overnment regulation No. 19 of 2005 concerning the National Education standard, which contains the determination of content/curriculum standards, graduate quality standards, process standards, standards for educators and education personnel, financing standards, infrastructure advice standards, management standards, and standards evaluation. These various laws and regulations are basically directed at efforts to improve the quality of education. These efforts, among others, are carried out by making improvements to various components of education, as well as various other efforts, such as reformulation of the human resource development paradigm, make tarbiyah islamiyah a superior education, make madrasas as the main choice, reformulation of the basic education curriculum Islam, the formulation of the concept of early childhood education, the formulation of character paradigm education, noble character education, character development

\section{LITERATURE REVIEW}

The global era demands that humans have global qualities too, humans worldwide. Therefore, Islamic education must be directed to this. Islamic schools, madrasas and boarding schools as well as Islamic universities must be directed at the creation of humans who can live in this world. Therefore it is necessary to make an Islamic education plan including:

1) Quality education. The global era is synonymous with the competitive era. With Thus, quality education is the mainstay.

2) Products that demonstrate their ability to meet needs direct or indirect customers, both the stated quality and implied by the present and the future. (Tampubolon, 2001: 108). In everyday life we often hear quality words. For example, quality food, quality paintings, quality lessons, and so on so. These quality words have meanings with good qualities. Thus, quality means having good or fun for those who feel it or also for the public. (Tampuboln, 2001:106)." Now the question arises how to create Islamic education that quality? With regard to that there are several factors that are closely related to establishment of quality (quality), namely: raw input (book materials), educators, facilities and facilities, methods, curriculum, management, environment, process learning.

1. Build integrated non-physical physical education (reason, qalb, nafs) and skills so that intellectually, emotionally, and spiritually.

2. Utilizing globalization technology teaching, learning technology long distance, use of computers, internet, teleconference, and others.

3. Expanding international cooperation networks.

The era of globalization inevitably has two impacts, namely positive and negative negative. Its positive impact makes human life easier by utilizing communication and transportation technology, shortening the distance far. The negative impact will be cultural competition and internal competition in various areas of life. The competition will be won by the strong. Strong cultures will 


\section{REGULATORY ISSUES AND CHALLENGES: GLOBAL NORMS AND RELIGIOUS CONSTRAINTS}

DOI: $10.54443 /$ ijebas.v2i1.137

dominate and will overpower weak. Including in the economic field. The increasing global influence of globalization has also spread to the fields of religion. It is undeniable that religious values are now fading. The emergence of new liberal thoughts! and tends to break the rules Religion makes people confused and in the end they fall into corners that compartmentalize religion. The presence of secularism paliam too adds to the limitations of religion in regulating human life. Secularism is an understanding that separates the affairs of the world from the affairs of religion. So, in worldly affairs it should not be mixed with religion, even though we should always put the two together in a circle so that there are harmonious life. Globalization comes along with capitalism. This thought market western ideology, and can remove religious authority The decline in the field of religion is also felt to be related to differences of opinion within one religion. For example, when determining holidays, there must be differences from each religious camp. The loss of religious values is very clearly visible in society nowadays, especially among teenagers. Free sex culture, drugs, drinking liquor, extravagance, greed have become commonplace. On the other hand, with this globalization, there are developments in the field of Religion is also quite profitable. For example, in relation to astronomical technology. The science of astronomy is increasing developed to make it easier for scholars to determine the times of holidays etc.

\section{METHOD}

1. Research methods

Types of research This type of research is library research, namely research through studies literature or to the literature that presents materials relating to the problem of the influence of globalization on Islamic religious values.

2. Data Types and Sources

This type of research is qualitative, namely explaining about problems explicitly and clearly, while the sources of this research data are: primary data, namely books that directly discuss the influence of Globalization of Islamic religious values

3. Results and Discussion

\section{a. Result}

Regulators from the developing world, including Islamic countries, now must be trained and counseled on an on-going basis by more experienced regulators. They have little choice, since the acceptance of new norms is the sine qua non to being allowed to expand abroad, or to have access to international financial markets

An overlapping network of governments (directly and through the G7 and G10),15 private corporations (including most large financial banks, securities companies and insurance companies), and international organizations (the World Bank, the International Monetary Fund [IMF], the Organization of Economic Cooperation and Development [OECD], the World Trade Organization [WTO], etc.) has played a key role in promoting global financial standards. This section focuses on two little-known organizations, the Group of Thirty, a private think-tank, and the Bank for International Settlements (BIS), 'the central bank of central banks', both of which were instrumental in shaping the new norms of financial regulation. At a time of harmonization of regulatory practices, the interest-free Islamic regulators have a hard time achieving convergence with interest-based conventional regulators. Interest rates have been an essential (and convenient) tool of regulation and control. By raising or lowering a variety of rates, regulators can influence the money supply and achieve specific policy goals. In an interest-free system, such a tool cannot in theory be used. 
Advocates of Islamic banking argue that other tools can be used - such as modifying reserve requirements for banks, injecting liquidity into the system (for example by manipulating surpluses or deficits), or imposing new 'lending ratios' (the proportion of demand deposits that commercial banks are obliged to lend out as interest-free loans) or 'refinance ratios' (the central bank refinancing of a part of the interest-free loans provided by the commercial banks). Original solutions have been offered to deal with issues such as deposit insurance or the ability to be lenders of last resort. It remains to be seen how such schemes can fit with new approaches to bank regulation as promulgated by the Basle Committee, or be 'harmonized' with the prevailing practices of other regulators.

\section{DISCUSSION}

An overlapping network of governments (directly and through the G7 and G10), private corporations (including most large financial banks, securities companies and insurance companies), and international organizations (the World Bank, the International Monetary Fund [IMF], the Organization of Economic Cooperation and Development [OECD], the World Trade Organization [WTO], etc.) has played a key role in promoting global financial standards. This section focuses on two little-known organizations, the Group of Thirty, a private think-tank, and the Bank for International Settlements (BIS), 'the central bank of central banks', both of which were instrumental in shaping the new norms of financial regulation.

\section{CONCLUSION AND SUGGESTIONS}

a. Conclusion

From the previous description it can be concluded that:

1. Islamic religious values are basic values that function to encourage humans or society to understand the relationship between God and nature universe. The appreciation of this value will give meaning to society in life so that it is not wrong to respond to the era of giobaiization which is getting worse day by day.

2. The influence of globalization on Islamic religious values inevitably changes the rules and values that we have considered established so far and we hold on firmly.

b. Suggestions

1. We must pay attention to one of the values contained in the teachings of Islam, because religion has an important role in this life, so that we are not wrong in facing the era of globalization that development is getting faster and faster.

2. Globalization has two impacts, namely positive and negative from both so that we are not wrong, we must be able to take it from only positive impacts because there are many negative impacts which can destroy the order of Islamic religious value

\section{REFERENCES}

Suharto, Toto, Idi, Abdullah, Revitalization of Islamic Education, Yogyakarta, Tiara Wacana Publisher, 2006

Tillar, Education for the New Indonesian Society, Jakarta, Discourse, 1998

Wahyudi, Applied Islamology, Surabaya, Gita Media Press,

Haefner, JE, Deli-Gray, Z., \& Rosenbloom, A. (2011), “The importance of brand liking and brand trust in consumer decision making: Insights from Bulgarian and Hungarian consumers during the global economic crisis", Managing Global Transitions : International Research Journal, Vol. 9 No.3, pp.249-273. 
Hafeez, S., \& Hasnu, S. (2010), "Customer satisfaction for cellular phone in Pakistan: A case study of Mobilink", Business and Economics Research Journal, Vol.1 No.(3), pp. 35-44.

Hafeez, S. and Muhammad, B. (2012), "The Impact of Service Quality, Customer Satisfaction and Loyalty Programs on Customer's Loyalty: Evidence from Banking Sector of Pakistan”, International Journal of Business and Social Science, Vol.3 No. 16, pp. 200-209.

Heriyadi, Listiana, E. and Lay, YN (2018). An Analysis of the Influence of Service Quality, Personal Selling and Complaint Handling and Trust on Customer Retention (Survey of Bank Harda International Savings Customers, Pontianak Branch). Volume 7 Number 2.

Ilham, R. N., Erlina, K. A. F., Silalahi, A. S., Saputra, J., \& Albra, W. (2019). Investigation of the bitcoin effects on the country revenues via virtual tax transactions for purchasing management. Int. J Sup. Chain. Mgt Vol, 8(6), 737.

Kotler.P. (2008). Marketing Principles 2. Twelfth Edition. Jakarta : Erlangga.

Nur Ilham, R. ., Arliansyah, A., Juanda, R., Multazam, M. ., \& Saifanur, A. . (2021). RELATHIONSIP BETWEEN MONEY VELOCITY AND INFLATION TO INCREASING STOCK INVESTMENT RETURN: EFFECTIVE STRATEGIC BY JAKARTA AUTOMATED TRADING SYSTEM NEXT GENERATION (JATS-NG) PLATFORM. International Journal of Economic, Business, Accounting, Agriculture Management and Sharia Administration (IJEBAS), 1(1), 87-92. https://doi.org/10.54443/ijebas.v1i1.27

Riinawati, R. (2021). Education Financial Management during Covid-19 Pandemic of Islamic Universities in South Kalimantan. Dinamika Ilmu: Jurnal Pendidikan, 383-396. 